\title{
Pemilihan Rumah Tinggal Menggunakan Metode Weighted Product
}

\author{
Heru Supriyono ${ }^{1 *}$, Chintya Purnama Sari ${ }^{2}$ \\ ${ }^{1}$ Program studi Teknik ELektro \\ Universitas Muhammadiyah Surakarta \\ Surakarta \\ *Heru.Supriyono@ums.ac.id \\ ${ }^{2}$ Program studi Informatika \\ Universitas Muhammadiyah Surakarta
}

Surakarta

\begin{abstract}
Abstrak
Pemilihan rumah tinggal termasuk salah satu contoh permasalahan pengambilan keputusan berdasarkan banyak faktor atau kriteria yang sifatnya semi-terstruktur. Tulisan ini menguraikan penelitian yang sudah dilakukan pada penyelesaian permasalahan pemilihan rumah tinggal dari berbagai alternatif yang ada dengan menggunakan metode Weighted Product (WP). Ada 11 faktor atau kriteria yang digunakan untuk proses pengambilan keputusan, masing-masing kriteria membunyai bobot kepentingan yang berbeda-beda. Besarnya bobot kepentingan masing-masing kriteria ditentukan melalui survei dan wawancara terhadap calon pembeli rumah dan karyawan pengembang perumahan. Sistem pemilihan rumah tinggal dengan metode WP diimplementasikan dalam sistem berbasis web. Tujuan dari penelitian yang sudah dilakukan adalah untuk menyediakan sebuah perangkat lunak berbasis web untk membantu meyelesaikan pemilihan rumah tinggal berbasis metode WP. Hasil pengujian menjukkan nilai perhitungan nilai preferensi dan skor akhir yang dihasilkan oleh sistem sama persis dengan hasil perhitungan manual yang menunjukkan bahwa sistem berbasis web yang dibangun adalah valid. Hasil pengujian menggunakan berbagai macam web browser menunjukkan bahwa sistem bisa berjalan dengan baik pada semua web browser.
\end{abstract}

Kata kunci: Pemilihan rumah tinggal; weighted product; sistem berbasis web.

\section{PENDAHULUAN}

Rumah atau tempat tinggal adalah salah satu kebutuhan pokok (primer) manusia disamping sandang dan pangan. Banyak faktor yang mempengaruhi setiap orang untuk memilih rumah tinggal diantaranya adalah harga rumah, luas tanah, luas bangunan, model rumah, jarak rumah ke jalan raya, jarak rumah ke tempat kerja, jarak rumah ke sekolah anak, adanya fasilitas keamanan lingkungan, jarak rumah dengan tempat belanja dan lain sebagainya. Faktorfaktor ini terkadang saling bertentangan misalnya rumah yang dekat dengan pusat keramaian harganya mahal atau rumah yang cocok dari segi harga, ukuran dan lokasi namun tidak tersedia tempat ibadah yang dekat dalam kompleks atau lingkungan tersebut. Sehingga, terkadang, apabila satu faktor terpenuhi maka faktor yang lain tidak terpenuhi. Kemungkinan solusi terbaik adalah dengan berusah mendapatkan titik penyelesaian yang optimal dengan mempertimbangkan semua faktor yang ada walaupun tidak paling memuaskan pada salah satu faktor.

Salah satu alternatif solusi untuk mendapatkan solusi yang optimal adalah dengan menerapkan suatu algoritma pengambilan keputusan yang disebut dengan fuzzy multiattribute decision making (FMADM). Salah satu metode dalam FMADM yang cukup terkenal adalah metode weighted product (WP). Metode WP cukup banyak digunakan untuk pengambilan keputusan karena metodenya yang sederhana dengan memasukkan semua faktor dan komputasinya cepat. Dari hasil penelusuran di internet dapat diketahui penggunaan metode WP untuk pemilihan rumah tinggal belum pernah dilaporkan oleh peneliti sebelumnya, oleh karena itu tim penulis mencoba menggunakan metode WP untuk pemilihan rumah tinggal.

Metode WP sudah cukup sukses diaplikasikan oleh beberapa peneliti sebelumnya seperti untuk pemilihan televisi layar datar [1], dan untuk diagnosis penyakit pneumonia [2]. Metode WP adalah metode untuk pengambilan keputusan berdasarkan besarnya nilai preferensi yang dihitung berdasarkan pada nilai variabel yang digunakan yang dipangkatkan dengan bobotnya. Semakin besar nilai preserensi suatu alternatif solusi maka alternatif solusi itu semkin disukai. Besarnya nilai preferensi dihitung dengan formula 1 sebagai berikut: 


$$
S_{i}=\prod_{j=1}^{n} x_{i j}{ }^{w}
$$

dengan $S_{i}$ adalah nilai preferensi alteratif ke-i, $i=1,2,3, \ldots m$ adalah indeks alternatif solusi yang tersedia, $j=1,2,3, \ldots . n$ adalah indeks faktor yang dipertimbangkan dalam proses pengambilan keputusan atau pemilihan alternatif solusi, $w$ adalah bobot untuk masing-masing faktor yang digunakan dalam proses pengambilan keputusan, $X_{j}$ adalah nilai variabel alternatif solusi ke-i untuk variabel ke-j. Dalam proses perhitungan nilai preferensi, $w$ akan bernilai positif apabila faktor tersebut merupakan atribut keuntungan namun akan bernilai negatif jika merupakan atribut biaya. Sebelum digunakan, nilai bobot harus dinormalisasi terlebih dahulu sehingga $\sum w_{j}=1$ dengan menggunakan rumusan 2 sebagai berikut:

$$
w_{j}=\frac{w_{j}}{\sum w_{j}}
$$

Skor akhir dari setiap alternatif solusi kemudian d hitung sebagai nilai normalisasi dengan rumusan 3 sebagai berikut:

$$
V_{i}=\frac{S_{i}}{\sum S_{i}}
$$

Dengan $V_{i}$ adalah nilai skor akhir masing-masing alternatif solusi, semaikin tinggi nilai skornya maka akan semakin disukai atau merupakan solusi yang paling optimal.

\section{METODE}

Pada penelitian yang kami publikasikan ini, pengambilan keputusan pemilihan rumah tinggal menggunakan metode WP diwujudkan dalam sebuah sistem berbasis web. Tahap-tahap pelaksanaan penelitian diantaranya adalah pengumpulan data melalui wawancara dan kuesioner kepada calon pembeli rumah tentang faktorfaktor utama pemilihan rumah tinggal beserta dengan bobot kepentingannya, perhitungan metode WP secara manual, perancangan sistem berbasis web, pengujian hasil eksekusi sistem berbasis web dibandingkan dengan hasil perhitungan manual. Sistem berbasis web untuk pemilihan rumah tinggal ini dibuat dengan menggunakan metode waterfall. Perangkat lunak utama yang digunakan dalam pengembangan web diantaranya adalah Macromedia Dreamweaver CS5, Xampp 1.8.1., dan MySQL DBMS.

\subsection{PENENTUAN KRITERIA PERTIMBANGAN DAN BOBOTNYA}

Dari hasil interview dengan masyarakat yang mepunyai pengalaman membeli rumah tinggal dan calon pembeli rumah tinggal serta beberapa karyawan bidang pemasran pada perusahaan pengembang perumahan, diambil 11 faktor utama yang digunakan oleh pembeli rumah tinggal untuk menentukan pilihannya. Kesebelas faktor beserta dengan bobot alternatifnya dapat dilihat pada Tabel. 1.

Tabel 1. Faktor/kriteria yang dipertimbangkan dalam pemilihan rumah tinggal beserta bobot relatif/ternormalisasinya serta kelompok atributnya. Keterangan besarnya bobot: 5

\begin{tabular}{|c|c|c|c|c|}
\hline No. & Kriteria & Bobot & $\begin{array}{l}\text { Bobot } \\
\text { Relatif }\end{array}$ & $\begin{array}{c}\text { Benefit/ } \\
\text { Cost }\end{array}$ \\
\hline 1. & Lokasi & 5 & 0,17 & Cost \\
\hline 2. & Harga & 5 & 0,17 & Cost \\
\hline 3. & Luas tanah & 2 & 0,07 & Benefit \\
\hline 4. & Luas bangunan & 2 & 0,07 & Benefit \\
\hline 5. & $\begin{array}{l}\text { Jumlah kamar } \\
\text { tidur }\end{array}$ & 1 & 0,03 & Benefit \\
\hline 6. & $\begin{array}{l}\text { Jumlah kamar } \\
\text { mandi }\end{array}$ & 1 & 0,03 & Benefit \\
\hline 7. & $\begin{array}{c}\text { Adanya sistem } \\
\text { keamanan }\end{array}$ & 3 & 0,1 & Benefit \\
\hline 8. & Jumlah lantai & 1 & 0,03 & Benefit \\
\hline 9. & Lingkungan & 4 & 0,13 & Benefit \\
\hline 10. & Fasilitas & 3 & 0,1 & Benefit \\
\hline \multirow[t]{2}{*}{11.} & $\begin{array}{c}\text { Jarak dengan } \\
\text { sekolah }\end{array}$ & 3 & 0,1 & Cost \\
\hline & & 30 & 1 & \\
\hline
\end{tabular}
$=$ sangat penting, 4 = penting, $3=$ cukup penting, $2=$ tidak begitu penting, 1 = tidak penting

Semua faktor atau kriteria pada Tabel 1 dibagi menjadi dua kelompok yaitu yang bersifat manfaat (benefit) dan yang bersifat biaya (cost). Suatu atribut akan disebut bersifat manfaat (benefit) kalau nilainya semakin besar semakin disukai sedangkan atribut yang bersifat biaya adalah apabila semakin besar nilainya semakin tidak disukai. Faktor atau kriteria yang termasuk atribut biaya adalah lokasi (jarak rumah dari jalan raya), harga rumah dan jarak dengan sekolah. Selain ketiga faktor tersebut semuanya merupakan atribut manfaat (benefit). Nilai-nilai ini dimasukkan oleh administrator pada sistem berbasis web yang dibuat.

\subsection{USE CASE DIAGRAM}

Berdasarkan levelnya, pengguna sistem berbasis web ini dibedakan menjadi dua yaitu sebagai pengguna biasa dan sebagai administrator. Sebagai administrator, pengguna bisa melakukan penambahan, pengeditan dan penghapusan pada berbagai menu yang tersedia seperti yang dapat dilihat pada Gambar 1. 


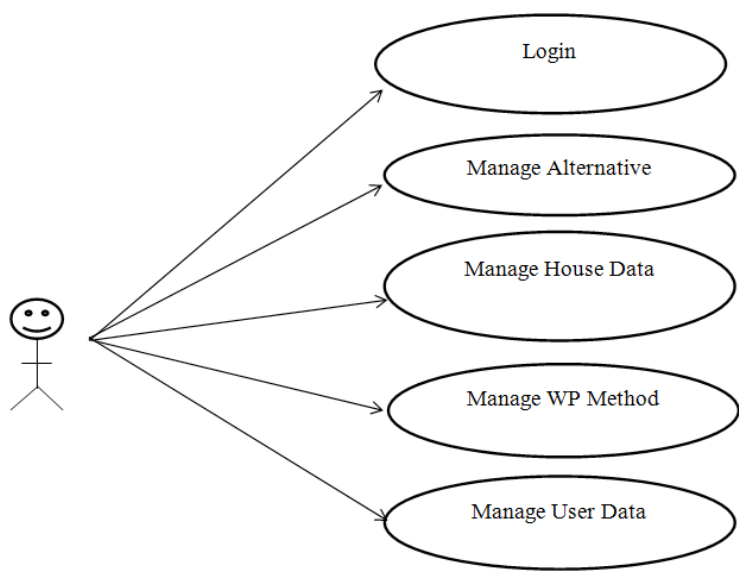

Gambar 1. Use case diagram untuk Administrator

Untuk aktor kedua yaitu sebagai user biasa, pengguna bisa melakukan login, memilih alternatif rumah yang ada, melakukan perhitungan dengan menggunakan metode WP dan lain sebagainya yang secara lengkap dapat dilihat pada Gambar 2.

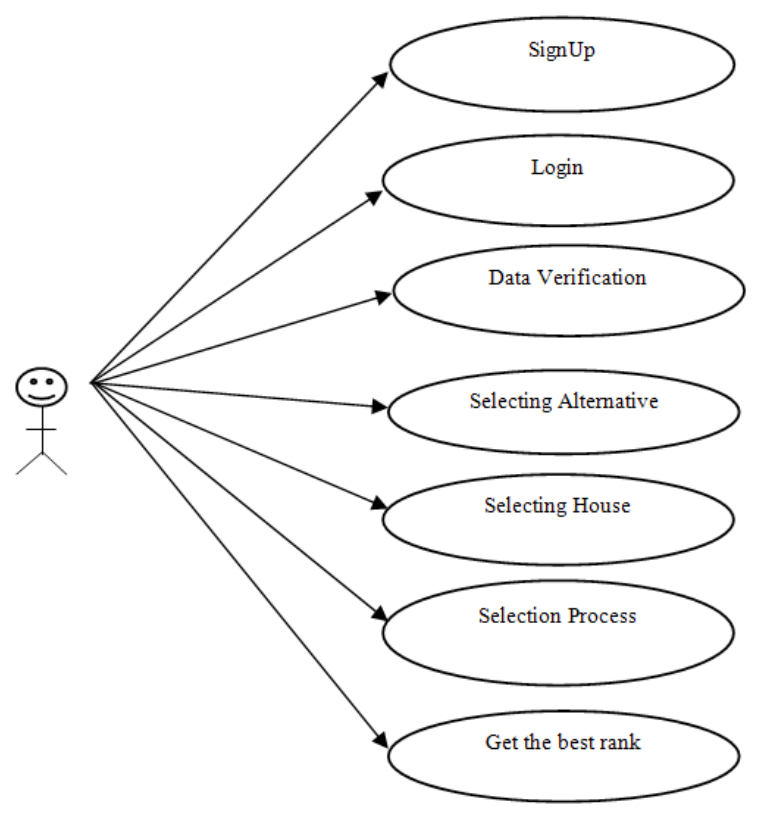

Gambar 2. Use case diagram untuk Pengguna

\section{House} SELLCTION

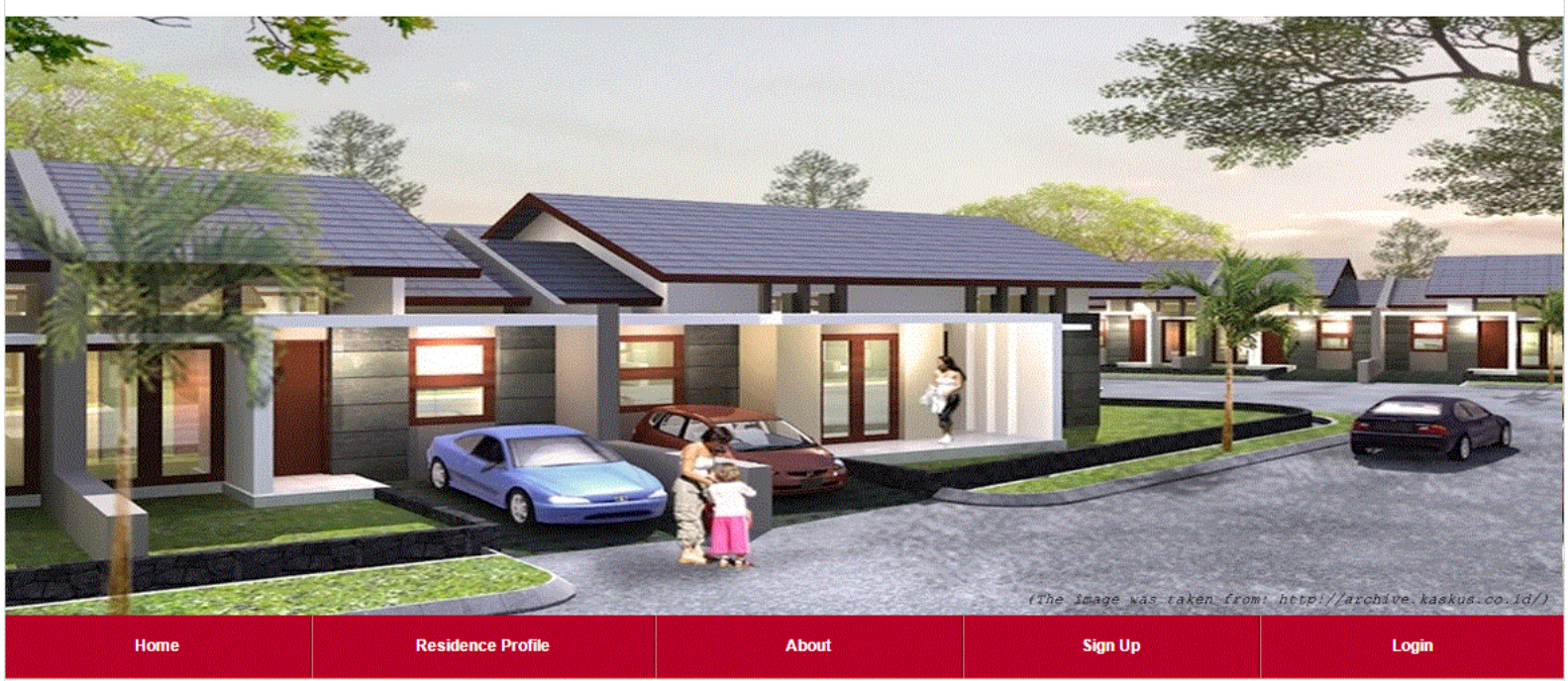

Gambar 3. Tampilan halaman utama sistem pemilihan rumah tinggal dengan metode WP berbasis web 
Hai Chintya Purnama

Data Perumahan

\begin{tabular}{|c|c|c|c|c|c|c|c|c|c|c|c|c|c|}
\hline No & WILAYAH & PERUMAHAN & $\begin{array}{l}\text { LOKASI } \\
\text { (M) }\end{array}$ & $\begin{array}{l}\text { HARGA } \\
\text { (RP) }\end{array}$ & $\begin{array}{l}\text { TANAH } \\
\left(\mathrm{M}^{2}\right)\end{array}$ & $\begin{array}{c}\text { BANGUNAN } \\
\left(\mathrm{M}^{2}\right)\end{array}$ & $\begin{array}{c}\text { JML KM } \\
\text { TIDUR }\end{array}$ & $\begin{array}{l}\text { JML KM } \\
\text { MANDI }\end{array}$ & $\begin{array}{l}\text { JAM KEAMANAN } \\
\text { (JAM) }\end{array}$ & $\begin{array}{c}\text { JML } \\
\text { LANTAI }\end{array}$ & LNGKUNGAN & FASILTAS & SEKOLAH \\
\hline 1 & Surakarta & $\begin{array}{l}\text { Perum Candi } \\
\text { Baru }\end{array}$ & 300 & 575 & 127 & 90 & 4 & 2 & 24 & 1 & 4 & 3 & 3 \\
\hline 2 & Surakarta & $\begin{array}{l}\text { Naso } \\
\text { Residence }\end{array}$ & 150 & 800 & 120 & 185 & 6 & 3 & 24 & 2 & 4 & 3 & 3 \\
\hline 3 & Surakarta & Griya Adipura 2 & 500 & 462 & 115 & 41 & 2 & 1 & 24 & 1 & 4 & 3 & 3 \\
\hline 4 & Surakarta & Fajar Mutiara 2 & 400 & 401 & 112 & 60 & 2 & 1 & 24 & 1 & 4 & 3 & 3 \\
\hline 5 & Surakarta & Tower Hills & 300 & 490 & 100 & 50 & 2 & 1 & 24 & 1 & 4 & 3 & 3 \\
\hline 6 & Surakarta & $\begin{array}{l}\text { Taman Fajar } \\
\text { Indah }\end{array}$ & 300 & 1000 & 105 & 150 & 3 & 2 & 24 & 3 & 4 & 3 & 3 \\
\hline
\end{tabular}

Pilih Perumahan Yang Anda Inginkan (maksimal 3 pilihan)

\begin{tabular}{|c|c|c|}
\hline Pilihan 1 & - Pilihan 1-- & $\boldsymbol{V}$ \\
\hline Pilihan 2 & - Pilihan 2-- & $\boldsymbol{v}$ \\
\hline Pilihan 3 & - Pilihan 3-- & $\boldsymbol{v}$ \\
\hline
\end{tabular}

- *Lokasi = Jarak perumahan dari jalan raya

- ${ }^{*}$ Harga = Harga dalam Juta Rupiah

- *Lingkungan, Fasilitas (tempat ibadah, taman bermain) dan Sekolah memiliki nilai bobot berdasarkan hasil interview beberapa sample calon pembeli

Gambar 4. Tampilan menupemilihan alternatif rumah tinggal yang akan dibandingkan dengan metode WP

\section{HASIL}

Tampilan utama sistem berbasis web pemilihan rumah berbasis WP dapat dilihat pada Gambar 3.Untuk dapat menggunakan sistem yang dibuat maka pengguna harus melakukan mendaftarkan diri untuk medapatkan user account dan kemudian log-in terlebih dahulu. Setelah log-in maka pengguna dapat memilih alternatif rumah yang akan dibandingkan dengan metode WP. Alternatif rumah beserta 11 criterianya sudah diinputkan oleh administrator. Tampilan menu pemilihan alternatif oleh pengguna dapat dilihat pada Gambar 4.
Setelah pengguna memilih tiga alternatif rumah tinggal yang akan dibandingkan, maka proses perhitungan dengan metode WP akan setelah pengguna menekan tombol process. Sistem kemudian memproses perhitungan yang hasil perhitungannya hanya akan muncul di tampilan adminsitrator seperti yang sapat dilihat pada Gambar 5. Data yang akan muncul dan dapat dilihat oleh pengguna adalah besarnya nilai preferensi untuk masing-masing alternatif dan skor akhir untuk masing-masing alternatif yang tampilannya dapat dilihat seperti pada Gambar 6.

Perumahan Yang Dipilih

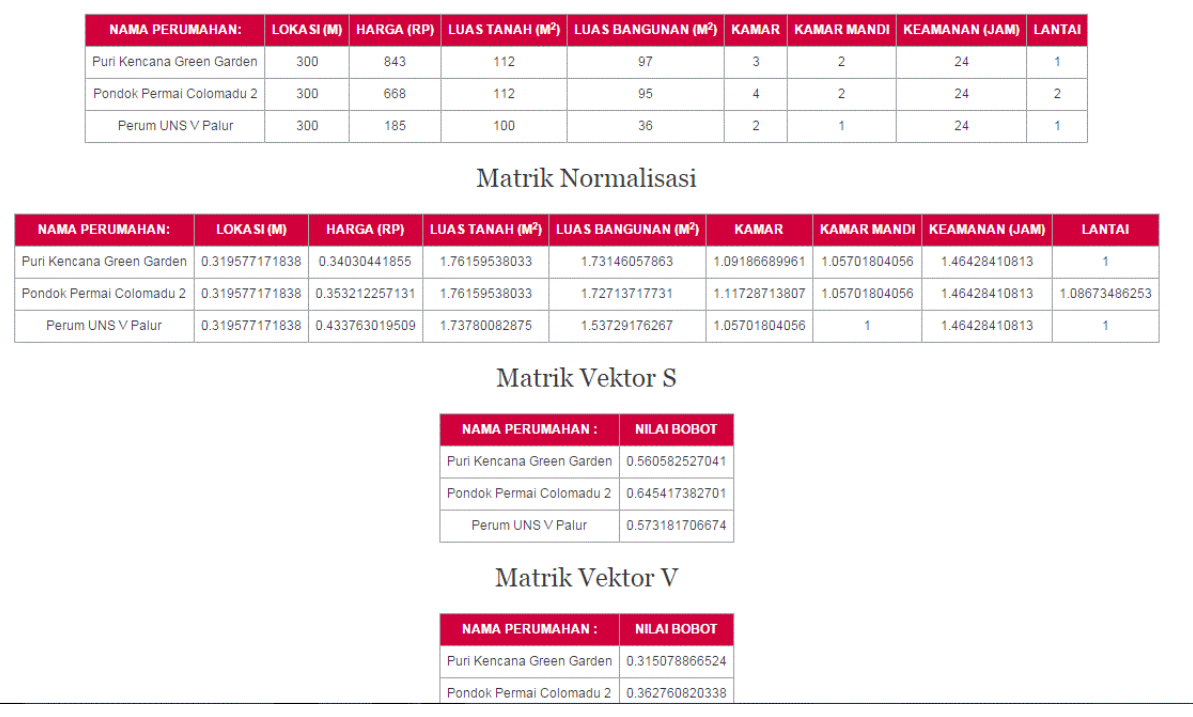

Gambar 5. Tampilan nilai-nilai pada proses perhitungan yang tampak pada antarmuka administrator 
Hai Chintya Purnama

\section{Vektor S}

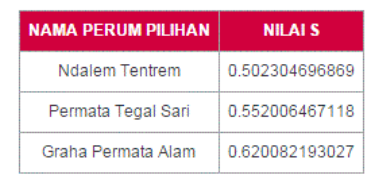

Hasil Perankingan Vektor V

\begin{tabular}{|c|c|}
\hline NAMA PERUMAHAN : & NILAIV \\
\hline Graha Permata Alam & 0.370332449319 \\
\hline Permata Tegal Sari & 0.329675499969 \\
\hline Ndalem Tentrem & 0.299992050712 \\
\hline & \\
\hline & CETAK
\end{tabular}

Gambar 6. Tampilan hasil pemrosesan pemilihan rumah dengan metode WP

Hasil perhitungan dengan metode WP baik nilai preferensi maupun nilai skor akhir ditampilkan dan hasil ini bisa dicetak. Untuk mengetahui apakah metode WP yang dibangun ini valid atau tidak maka perlu dilakukan proses validasi. Proses validasi dilakukan dengan cara membandingkan hasil perhitungan nilai preferensi (S) dan skor akhir (V) dengan metode WP dari sistem dan hasil perhitungan secara manual menunjukkan hasil yang sama yang menunjukkan bahwa metode WP yang dibuat dengan sistem berbasis web valid. Contoh perbandingan hasil perhitungan antara hasil dari sistemberbasis web dan hasil perhitungan manual dapat dilihat pada Tabel 2.

Tabel 2. Perbandingan hasil perhitungan untuk nilai preferensi (S) dan skor akhir (V) hasil keluaran sistem vs perhitungan manual

\begin{tabular}{|c|c|c|c|c|c|}
\hline \multirow[t]{2}{*}{ No } & \multirow{2}{*}{$\begin{array}{c}\text { Alternatif } \\
\text { Rumah } \\
\text { Tinggal }\end{array}$} & \multicolumn{2}{|c|}{$\begin{array}{c}\text { Hasil } \\
\text { Perhitungan } \\
\text { Sistem } \\
\end{array}$} & \multicolumn{2}{|c|}{$\begin{array}{c}\text { Hasil } \\
\text { Perhitungan } \\
\text { Manual }\end{array}$} \\
\hline & & $\mathbf{S}$ & V & $\mathbf{S}$ & V \\
\hline 1 & $\begin{array}{c}\text { Perum. Candi } \\
\text { Baru }\end{array}$ & 0,5403 & 0.3307 & 0,5403 & 0.3307 \\
\hline 2 & Naso Residence & 0,6298 & 0.3855 & 0,6298 & 0.3855 \\
\hline 3 & Griya Adipura 2 & 0,4635 & 0.2837 & 0,4635 & 0.2837 \\
\hline
\end{tabular}

\section{DISKUSI}

Tahap paling akhir dalam penelitian yang dipublikasikan ini adalah dengan menguji sistem berbasis web yang dibuat pada berbagai macam web browser yang populer atau banyak digunakan oleh masyarakat dan pada berbagai perangkat mobile dengan ukuran layar yang berbeda-beda. Hasil pengujian menunjukkan sistem berbasis web bekerja dengan baik untuk tiga buah web browser yaitu Mozilla Firefox, Internet Explorer, Google Chrome, dana Safari. Hasil pengujian pada perangkat mobile menunjukkan tampilan sistem bisa mengikuti ukuran layar (responsif).

Pengujian terakhir yang dilakukan adalah pengujia tingkat penerimaan pengguna (user acceptance test/
UAT). UAT dilakukan dengan cara meminta responden yang merupakan orang yang mempunyai pengalaman membeli rumah, orang yang akan membeli rumah, dan karyawan bagian pemasaran perusahaan pengembang perumahan untuk mencoba sistem yang dikembangkan dan kemudian mengisi kuesioner yang sudah disiapkan. Responden diminta untuk menjawab beberapa pertanyaan meliputi: P1. Apakah aplikasi yang dikembangkan ini cukup mudah digunakan?, P2. Bagaimana pendapat anda mengenai tampilan desain dan warna pada aplikasi ini?, P3. Apakah penilaian pada sistem pakar sesuai dengan kebutuhan?, P4. Bagaimana aplikasi ini membantu anda dalam memilih rumah?, P5. Bagaimana penampilan desain menu pada aplikasi ini?, P6. Bagaimana pendapat anda mengenai kelengkapan menu pada aplikasi ini?, P7. Bagaimana pendapat anda tentang keseluruhan aplikasi ini?. Untuk setiap pertanyaan, disediakan empat buah alternatif jawaban yang kemudian di skala yaitu: tidak baik $=2.5$, cukup baik $=5$, baik $=7.5$, sangat baik $=10$. Responden diminta untuk memilih salah satu jawaban saja. Kemudian nilai untuk masing-masing pertanyaan diwujudkan dalam nilai persentase yang dihitung dengan rumusan 4 .

$$
Q=\frac{J}{R} \times 100 \%
$$

Dengan Q adalah nilai persentase untuk setiap pertanyaan, adalah hasil penjumlahan nilai untuk masingmasing pertanyaan untuk semua responden, dan adalah jumlah responden. Semakin tinggi persentase yang didapatkan untuk masing-masing pertanyaan menunjukkan kalau sistem semakin disukai oleh responden. Hasil pengolahan data kuesioner menunjukkan nilai persentase untuk masing-masing pertanyaan adalah $60 \%$ responden puas untuk P1, 70\% responden puas untuk P2, 50\% responden puas untuk $\mathrm{P} 3,60 \%$ responden menjawab puas untuk $\mathrm{P} 4,60 \%$ responden menjawab puas untuk $\mathrm{P} 5,50 \%$ responden puas untuk $\mathrm{P} 6,70 \%$ responden puas untuk $\mathrm{P} 7$. 


\section{KESIMPULAN}

Dari hasil pengujian dan pembahasan dapat disimpulkan bahwa metode WP telah berhasil diimplementasikan dalam pemilihan rumah tinggal dengan berdasarkan 11 faktor kriteria yang digunakan. Sistem pemilihan rumah tinggal dibuat menjadi sistem berbasis web. Hasil pengujian menunjukkan nilai preferensi dan skor akhir keluaran sistem yang dibuat sama persis dengan hasil perhitungan manual yang menunjukkan validitas sistem berbasis web yang dibuat. Hasil pengujian dengan berbagai web browser menunjukkan sistem bekerja dengan baik pada semua web browser. Sistem berbasis web juga responsif sehingga tampilannyatetap cantik pada berbagai ukuran layar perangkat mobile.

\section{PERSANTUNAN}

Hasil penelitian yang dipublikasi ini merupakan sebagian skripsi tingkat sarjana pada Program Studi Informatika Fakultas Komunikasi dan Informatika oleh Chintya Purnama Sari.

\section{DAFTAR PUSTAKA}

[1] W. Y. Ningrum, Sistem Pendukung Keputusan untuk Merekomendasikan TV Layar Datar Menggunakan Metode Weighted Product (WP), Skripsi Program Studi Teknik Informatika Universitas Kristen Satya Wacana, 2012.

[2] M. Syaukani, dan H. Kusnanto, Pemodelan Sistem Pendukung Keputusan Kelompok Dengan Metode Fuzzy Weighted Product Untuk Diagnosis Penyakit Pneumonia, Jurnal Teknologi Volume 5 No. 1, pp. $17-23,2012$. 